\title{
The Meaning of Work during Short-term Unemployment ${ }^{1}$
}

\author{
Pedro F. Bendassolli \\ Fellipe Coelho-Lima \\ Rafaele de Araújo Pinheiro \\ Pollyanna Carvalho de Siqueira Gê \\ Universidade Federal do Rio Grande do Norte
}

\begin{abstract}
This paper reports the results of an investigation of the meanings unemployed people attribute to their work. The sample comprised 358 short-term (from one to six months) unemployed workers. Data were collected using a standardized questionnaire based on a five-dimensional meaning of work model that was previously adapted to the Brazilian context. The data were submitted to a confirmatory factor analysis. The results suggest that there might not be specificities in the meanings unemployed workers attribute to their work, considering that the five-factor structure of the meaning of work model was empirically supported. The results indicate that the variables length of unemployment, number of formal jobs, age, and schooling were significantly correlated with the number of dimensions of the meaning of work model.
\end{abstract}

Keywords: meaningful work; meaning of work; unemployment

\section{Sentido do Trabalho em Situação de Desemprego de Curta Duração}

\begin{abstract}
RESUMO - O objetivo deste artigo é relatar os resultados de uma investigação sobre sentidos atribuídos ao trabalho por pessoas desempregadas. A amostra foi composta por 358 desempregados de curta duração (de um a seis meses). Utilizou-se instrumento associado a um modelo de sentidos do trabalho composto por cinco dimensões teóricas, e previamente adaptado ao contexto brasileiro. Os dados foram submetidos a uma análise fatorial confirmatória. Os resultados indicam que parecem não haver especificidades nos sentidos atribuídos ao trabalho por desempregados, haja vista que a estrutura fatorial do modelo de sentidos, concebido para trabalhadores empregados, foi empiricamente confirmada. As variáveis tempo de desemprego, número de empregos formais, idade, e escolaridade mostraram-se significativamente relacionadas com dimensões do modelo de sentidos do trabalho adotado.
\end{abstract}

Palavras-chaves: sentidos do trabalho, significado do trabalho, desemprego

According to a report produced by the International Labour Organization (ILO, 2014), in 2013 the world population of unemployed workers was 199,8 million, and this statistic was estimated to increase over the next five years. In developing countries, however, unemployment rates have shown a historic decline. In Brazil, we have seen a decline in unemployment rates since the 2000 s - due, among other factors, to policies focused on market development and internal consumption and income distribution (Cacciamali \& Cury, 2013). According to research from the Inter-Union Department of Statistics and Socioeconomic Studies (DIEESE, 2014), 18,7\% of the country's population were unemployed in 1998, compared to $10,3 \%$ in 2013. The National Sample Survey of Households (PNAD) conducted by the Brazilian Institute of Geography and Statistics (IBGE, 2013) confirms this trend: in 2002, unemployment reached $9,14 \%$ of the labor force, and this figure was reduced to $6,72 \%$ in 2011 (Chahad \& Pozzo, 2013).

These data are not exactly news. Since industrialization began to accelerate in the West in the nineteenth century,

1 Agradecimento - Agradecemos o apoio da Secretaria do Estado de Trabalho, Habitação e Assistência Social do Rio Grande do Norte.

2 Endereço para correspondência: Universidade Federal do Rio Grande do Norte, Campus Universitário, Centro de Ciências Humanas Letras e Artes, Departamento de Psicologia, Natal, RN, Brasil. CEP: 59078970.E-mail: pbendassolli@gmail.com unemployment has been a recurring theme on government and civil society agendas (Galeazzi, 2011). The roots of the phenomenon lie in the operating logic of modern capitalism, and itdoes not have a single-cause explanation. Several theories and accumulated empirical evidence have established unemployment as a complex, multidetermined phenomenon, subject to political, social, and economic changes (Mclaughlin, 2013). In the field of psychology, research on the subject dates back to the 1930s, beginning with the seminal study by Jahoda, Lazarsfeld, and Zeisel (1933/1971) on the Marienthal community.Since then, and aligned with the cycles of economic expansion and downturn, the study of unemployment has intensified in psychology research and offers a wide range of theoretical perspectives and interventions (Paul \& Moser, 2006a).

Although unemployment is widespread, defining unemployment is an increasingly challenging task, given the complexity of the forms of work today. However, two definitions will be useful for our purposes. The first definition, that of the International Labour Organization (ILO, 1982), defines an unemployed individual as one who:(a) does not have formal paid employment or is in a situation of selfemployment,(b) is looking for a new position (for a week or a month) but has not been successful, and (c) is able to work. The second definition, provided by a Brazilian institutionfor the local contextand similar to the previous one, is the one 
given by DIEESE (1984), which assigns the status ofbeing unemployed to "individuals who are in aninvoluntary nonwork situation, caused by a lack of job opportunities, or individuals whoare performing irregular work with a desire for change"(p.9; author's translation). This definition includes people who do not have any form of income and are looking for employment (open unemployment), but also those working in the informal market who seek formalized insertion in the job market (unemployment hidden by precarious work). The DIEESE statistics presented at the opening of this section reflect this definition.

Another characterization of unemploymentconcerns its duration. If, in other historical moments - especially during periods of high economic growth (full employment) unemployment was seen as a transitory situation, this scenario has changed. According to some authors (e.g., Antunes, 2009; Garcia, Rodarte, \& Braga, 2006), a contingent of unemployed workers who are unlikely to be reinserted in the formal labor began to appear in the 1970s. This came to be known as structural unemployment, and it is largely explained by the disappearance of jobs due to technological advances, which especially affects older workers who are less qualified (Gómez, Morejon, \& Sabater, 2008).

Additionally, due to the heterogeneity of the current labor market, a person can now alternate between employment and unemployment, or stay in hidden unemployment or precarious or informal jobs for a long period of time (Dooley \& Prause, 2004). As a result, two other categories are also necessary for understanding the phenomenon of unemployment: long-term and short-term unemployment. The first is defined as unemployment for at least six months. Therefore, short-term unemployment is limited to a period of one week to six months (Winkelmann, 2014).

For decades, researchers have established relations between the duration of unemployment and the deterioration of multiple mental health indicators. This is one of the most traditional research fronts in unemployment psychology (e.g., Aaronson, Mazumder, \& Schechter, 2010; Janlert, Winefield, \& Hammarström, 2014; Jones, 1992; McKee-Ryan, Song, Wanberg, \& Kinicki, 2005; Winefield, Tiggemann, Winefield, \& Goldney, 1993). The research results in the Brazilian context converge with the international literature, insofar as these also support the negative impact of unemployment on various mental health parameters (e.g., Argolo \& Araújo, 2004; Bastos, 2011; Barros \& Oliveira, 2009; Coelho-Lima, Costa, \& Bendassolli, 2013; Pinheiro \& Monteiro, 2007; Santos et al., 2010).

There is a consensus that the vein of research that explores the relationship between unemployment and mental health indicators is the most consolidated in the psychological literature (McKee-Ryan et al., 2005). Yet there is also recognition of a need to broaden the analytical perspectives on this phenomenon beyond its deleterious effects in those relationships (e.g., Mohr \& Otto, 2011; Paul \& Moser, 2006a; Winefield, 2002). This study aims to contribute to this latter research direction, examining the relationship of unemployment to the meanings that unemployed people in a northeast Brazilian capital attribute to work as problematic. In doing so, this study also contributes to the investigations that are interested in the meaning of work in the unemployment situation - a minor branch of the literature, compared to the branch focused on the psychosocial impacts of unemployment on health and well-being.

One of the first initiatives in the direction of investigating the afore mentioned problematic was Brief, Konovsky, Link and Goodwin's (1995) study. Defining the meaning of work based on its economic and experiential functions, the authors demonstrated that when people are unemployed, they perceive a diminished economic function of labor, which in turn leads to a diminished experiential function (work is no longer a sphere of subjective importance). Moreover, it is this subjective deprivation that leads to a lower perception of well-being.

In another study, Paul and Moser (2006b) define unemployment as a situation of inconsistency between a desired job (evaluated based on commitmentto and involvementin work and the work ethic) and the individual's current status as unemployed. Thus, they affirm the importance of the meaning of work in subjective reactions to unemployment. Similarly, in a meta-analysis study, McKeeRyan et al. (2005) found that a high centrality of work has a negative impact on the physical and mental well-being of the unemployed. That is, the higher the centrality of work, the greater the possibility that the person will suffer when unemployed (see also McKee-Ryan \& Kinicki, 2002). Hetschko, Knabe, and Schob (2013) highlight the relationship between work and one's identity, which is undermined during unemployment.

Continuing in this vein, Hoorn and Maseland (2013) show that in countries where the values of the Protestant work ethic prevail, people suffer more from unemployment situations. Mohr and Otto (2011) show that in order to fulfill its role in restoring mental health, a new job taken up by an unemployed person must have meaning. Otherwise, either the effectof the new job on mental health will decrease with time or the person will end up leaving the job, returning to the unemployment situation. Finally, Ezzy (1993) points out that the more positive the representation of work is for a person, the more its loss will be felt. These studies reinforce the heuristic power of investigating the meanings attributed to work in order to understand the relation of the individual to unemployment. However, we must ask, of what does this meaning consist?

The question of the interpretation that workers attach to their work has mobilized researchers from various fields.In psychology, the question is investigated in field studies about the sense and meaning of work. These studies have occurred mostly since the late 1980s, with research focusing on the work of the Meaning of Work Research Team (MOW, 1987), which contributed to an understanding of the meaning of work as a cognition with a multiplicity of facets and determinants (Bendassolli \& Gondim, 2014). More recently, with the emergence of positive psychology and the recastingof the existentialist perspective in these field studies, a new focus of investigation was established around the perspective of "meaningful work,"defined as work that has a positive valence for the subject, that is, not merely a representation of a descriptive/cognitive nature (Steger, Dik, \& Duffy, 2012). 
This study adopts a model that is located closest to this second perspective: the model of the meaning of work proposed by Morin $(1997,2001,2007)$ and Morin and Dassa (2006), for whom "the meaning of work is an effect of coherence between the characteristics that the subject seeks in his work and those he realizes in the work he performs" (Morin, 2007, p. 5; author's translation). This model was developed by incorporating three theoretical influences. The first is Hackman and Oldham's job enrichment theory, according to whicha variety of tasks, an identity and meaning assigned to work, autonomy, and feedback are capable of producing motivation and commitment. The second is Emery and Trist's sociotechnical approach, which identifies six job properties that foster commitment: variety and challenge, continuous learning, leeway and autonomy, recognition and support, meaningful social contribution, and a desirable future. Finally, Morin's research was also influenced by the humanistic-existential perspective, according to which the self is oriented towards self-realization and self-development through work (Morin, 1997; Morin, Tonelli \& Pliopas, 2007).

Integrating these perspectives, Morin (1997, 2001, 2007) defines the meaning of work as an affective structure consisting of three dimensions related to several factors (Figure 1): significance, related to values and representations attributed to the work; orientation, related to the intentions that guide the actions that are taken; and coherence, which is how workers perceive harmony between the resultsthey get at work and their existential expectations (Morin, Tonelli, \& Pioplas, 2007). This model has already been used for several years by Brazilian researchers (for an overview, see Bendassolli \& Borges-Andrade, 2011; Silva \& Tolfo, 2012; Tolfo, Coutinho, Baasch, \& Cugnier, 2011).

In this study, the general purpose of investigating unemployment from the perspective of the meaning attributed to work unfolds in four specific operational questions: (a) Are there specificities in the meanings that the unemployed attribute to work? (b) How does the duration of unemployment influence the meaning attributed to work? (c) How does the number of formal jobs held relate to the assignment of meaning to work? (d) How does the unemployed person's profile (age, gender, education, and household income composition) relate to this meaning?

By specificities in attributed meaning (Question 1), we mean the existence of an empirical structure of meaning

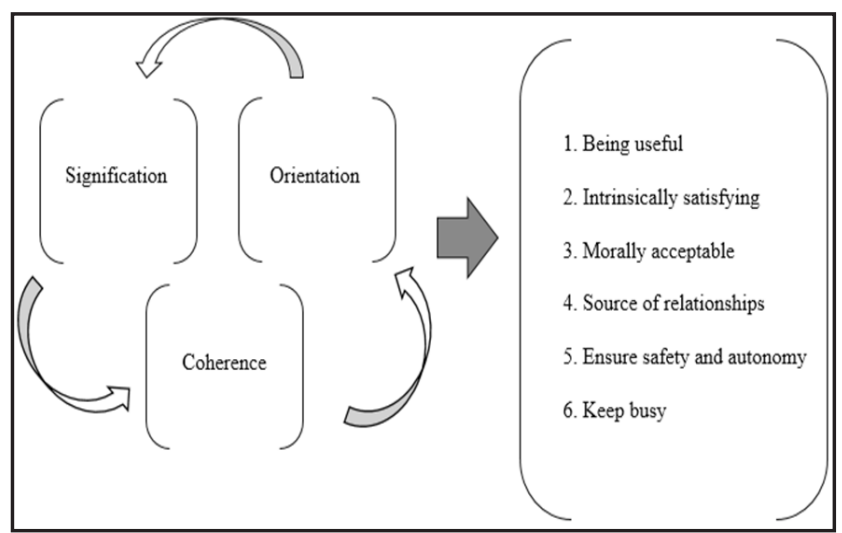

Figure 1.Meaning of work theoretical model.Ellaboration by the authors based on Morin (1997. 2001. 2007). factors among the unemployed similar to that found among employed workers. Although this study is not comparative in nature (employed vs. unemployed), the strategy we adopt to answer Question 1 is to use an instrument for the meaning of work that has been validated for employed people. This is the instrument inspired by the Morin model $(1997,2001)$ and operationalized by Morin and Dassa (2006). This instrument has previously been validated for the Brazilian context (Bendassolli \& Borges-Andrade, 2011). Our hypothesis is that if a confirmatory procedure (confirmatory factor analysis) shows that the structure provided by the original model satisfactorily fits the data for the unemployed, then we will have evidence for a negative answer to Question 1.

Question 2 derives from published findings that point to the influence of unemployment duration in predicting psychosocial phenomena associated with unemployment (e.g., Chen et al., 2012; McKee-Ryan et al., 2005; Schunck \& Rogge, 2010). Question 3 is based on the premise that work experience (in formal employment) may be related to the meaning attributed to work, specifically, in the acception of the meaning of work adopted in this study (Morin, 1997, 2001). Because the instrument developed by Morin addresses the characteristics that such work must have in order to be meaningful, it seems reasonable to assume that work socialization (inferred from work experience) can influence the structure of meaning assigned to work, even for unemployed workers.Finally, Question 4 reflects variables that are often cited in the literature as related to unemployment: age (e.g., Gallo, Bradley, Siegel, \& Kasl, 2000), sex (e.g., Rantakeisu, Starrin, \& Hagquist, 1999), education (e.g., Vesalainen \& Vuori, 1999), and house hold income composition (e.g., Estramiana, 1992; Kelvin \& Jarrett, 1985).

\section{Method}

\section{Participants}

The sample consisted of unemployed workers who accessed the units of the National Employment System (SINE) in the city of Natal/RN.The sampling strategy was accidental sampling, resulting in a total of 358 participants. However, as an inclusion criterion, participants had to be unemployed at the time of the survey. In fact, almost the entire population served by the SINE units in question consists of people seeking new formal job opportunities (unemployed people). We found that many had informal employment, but this did not act as an exclusion criterion because, according to the ILO and DIEESE definitions given in the introduction, this is also considered to be an unemployment situation. Thus, the only exclusion criterion was having a formal work contract. The length of unemployment was not considered as an inclusion or exclusion criterion. However, as described below, the entire sample was composed of people who were in this condition for no more than six months, i.e., short-term unemployed persons (Winkelmann, 2014).

In demographic terms, $53.9 \%$ of the participants were youngsters ( $15-29$ years), $45.8 \%$ were adults ( $30-59$ years), 
and only $0.3 \%$ were over 60 years. The sample was divided in practically the same way with regard to sex, with $51.7 \%$ male. The personal income of most participants $(86.1 \%)$ was not more than twice the minimum wage at the time of data collection. Turning to education, $52 \%$ had an incomplete higher education, $13.2 \%$ had completed high school, 10.1\% had completed higher education, 9.8\% had some type of graduate degree, $8.4 \%$ had completed primary education, and $5.9 \%$ had an incomplete secondary education $(0.6 \%$ of the participants did not provide this information). For family income, $92 \%$ of the participants had the support of another, either one $(34 \%)$, two $(44 \%)$, or three $(13 \%)$ people (spouse or relatives). The average duration of unemployment was 1.69 months $(\mathrm{SD}=1.0)$, with an absolute variation from one to six months.

\section{Instrument}

We used a scale for the meaning of work that was developed based on Morin's $(1997,2001,2007)$ theoretical model. This 25-item version (Morin \& Dassa, 2006) was translated and adapted to the Brazilian context by Bendassolli and Borges-Andrade (2011). When using the scale (for Canadian workers in the health field and French-Canadian managers), Morin obtained several factorial solutions through exploratory analyses. The final structure that resulted in the 25 items provides saturation in five factors, which is the model adopted here to perform the confirmatory factor analysis.

The five factors found by Morin and Dassa (2006), with their reliability indexes (Cronbach's alphas), are as follows: Learning and Development (.89), with items addressing how much work enables growth, skill development, and expressiveness; Quality of Work Relationships (.85), evaluating the work environment, interactions, and companionship at work; Work Utility (.84), with items assessing the social function of work and its impact on people and society; Autonomy (.77), evaluating the perception of the subject's freedom to organize work his or her own way; and Ethics $(0,90)$, addressing the perception of justice and fairness in labor relations.

The scale was presented with four response options: 1 (strongly disagree), 2 (somewhat disagree), 3 (somewhat agree), and 4 (strongly agree). Sociodemographic questions were also added, concerning age, sex, educational level, length of time unemployed, number of formal jobs held in the past two years, and the household income composition profile. Since the instrument was initially designed to be applied to employed people, we proceeded with a pre-test involving approximately 20 people with a similar profile to the target participants. The objective was to determine any need for adjustments, which proved necessary. In our view, this may be related to both the profile of the sample and the fact that the instrument contains issues that induce people to think about work in general and also about a particular job, the current job. Because of this ambiguity, we decided to enter the instruction that when responding, participants should take into account their recent work experience.

\section{Data collection procedure}

This research was developed in the broader context of a partnership with the Department of State for Labour, Housing and Social Assistance of Rio Grande do Norte. This city's unemployment rates have reflected the national profile since 2000. In 2012, the unemployment level in the state was at $7.1 \%$, which is close to the national average (7.6\%; IBGE, 2013).

The instrument application sites were the units of the city's SINE. The collection took place between November 2013 and April 2014 in four units that were active at the time of the research. Researchers visited the SINE units at different times and approached the people waiting for service. The application was divided into three stages: presentation of the researcher and research, followed by clarification of the procedures to be adopted and ethical care (anonymity, purpose of the information, risks and benefits), and finally, assisted (presential) application of the questionnaire. In the case of workers with a lower educational level, cards were used with different colors and shades to illustrate the Likert scale for each issue. The entire application procedure took about 30 to 60 minutes. All ethical considerations involving human research were observed.

\section{Data analysis procedure}

We explored the data in order to identify omissions and the profile of the distribution, in view of the requirements that are necessary for conducting the type of analysis we adopted. In all, we identified 11 missing cases, and as these represented only $2 \%$ of the total sample, we decided to exclude them (listwise deletion). The number of participants previously presented took these exclusions into account. We also found six variables with extreme univariate outliers (z-score $\geq$ 3,9 ) that accounted for $1 \%$ to $3 \%$ of the total number of respondents to these variables. However, we chose not to delete these, given that the next step of the analysis was to identify multivariate outliers, those with the greatest impact on the type of analysis to be performed. Based on inspection of the Mahalanobis distance for each respondent $(\mathrm{p}<0.01)$, 31 cases were identified and excluded.

Observing the values of asymmetry and kurtosis, we noted that these do not exceed the limits given by Kline (2011) and Marôco (2010) as critical for conducting a confirmatory factor analysis based on the estimation of maximum likelihood $(|\mathrm{sk}|<2-3 ;|\mathrm{ku}|<7-10)$, which was the method we adopted. The range of values found in the data, with the correction for the elimination of multivariate extreme cases, were $\mid$ sk $|: .63-2.0 ;| \mathrm{Ku} \mid: 0.1-4.0$. However, the Mardia coefficient indicates that the data differ from multivariate normality. For this reason, and considering the size of the sample (for which other estimation methods are discouraged-see Marôco, 2010), we decided to perform bootstrapping procedures (with replications from 1,000 samples and a $99 \%$ confidence interval) to ensure greater reliability of the parameters obtained.

The assessment of the overall quality of the adjustment used the indicators in Table 1, based on Byrne (2010), Kline 
(2011), and Marôco (2010), as a reference. For evaluating the quality of the local adjustment of the model, the factorial validity (standardized factor weights $\lambda \sim .50$ ), the items' reliability $(\mathrm{R} 2 \geq .25)$, and the internal reliability of the factors/latent variables based on Cronbach's alpha $(\alpha \sim$.70) were considered. Factor analysis was performed with the AMOS software, version 21. After the empirical structure was verified, average comparisons were made between the ANOVA and the student's t-test, and a correlation analysis (Pearson test) was conducted between meaning factors and descriptive variables.

\section{Results}

Table 1 shows the adjustment indices for the original model and the respecified model. Concerning the former, we note that, although a minimal acceptable solution was found by AMOS, this solution presents unsatisfactory adjustment indices, thus requiring changes. The first set of changes consisted of checking the standardized factor weights for each item. At this stage, it was found that two items had values below the value stipulated as a minimum criterion $(\lambda$ $\sim$.50). Thus, we excluded items 01 (concerning doing a job fittingthe individual's skills) and 07 (concerning exercise of the individual's judgement to solve problems at work).

A second adjustment, indicated by the AMOS modification indexes, concerns the corre-lation between errors of items within a single factor. Three cases were identified: two in factor 4, Learning and Development, between items 09 ("My job allows me to improve myself") and 13 ("My job allows me to learn") and between 04 ("Doing my job gives me great satisfaction") and 22 ("I take pleasure in doing my job"), and one in factor 3, Work Utility, between items 02 ("My work is useful to society") and 05 ("My work contributes to society"). We opted to allow these errors to covary freely amongst themselves. The correlation is most probably associated with the similarities in the semantic formulations of these pairs of items (especially in the Portuguese version), indicating overlap or redundancy between them.

With these changes, there is a notable improvement in the fit indices for the respecified model (Table 1). All the model parameters proved to be significant $(\mathrm{p}<.001)$.

Table 1. Indexes of Adequacy of the Five Factors Model of Meaning of Work

\begin{tabular}{ccc}
\hline Index & Original Model & Respecified Model \\
\hline$\chi 2$ & 790.36 & 409.39 \\
Gl & 265 & 177 \\
$\chi 2 / d f$ & 2.98 & 2.31 \\
GFI & 0.84 & 0.90 \\
TLI & 0.85 & 0.92 \\
CFI & 0.86 & 0.93 \\
RMSEA & 0.07 & 0.06 \\
\hline
\end{tabular}

Note: GFI = Goodness-of-Fit Index; TLI = Tucker-Lewis Index; $\mathrm{CFI}=$ Comparative Fit Index; RMSEA = Root Mean Square Error Approximation. Parameters estimated under $\mathrm{p}<0,001$. The reference values (Byrne, 2010; Kline, 2011; Marôco, 2010) are: GFI, TLI and CFI $\geq 0,90 ;$ RMSEA $\sim 0,05 ; \chi 2 \bigvee$ df $\sim 1 ; \chi 2=$ the lower, the better
Table 2 presents the standardized estimation coefficients, together with the (minimum-maximum) range produced by the bootstrap replications. In a visual inspection, we noted that the observed factor weights do not differ much from the range of values arising from those replications, which indicates that although the data do not exhibit multivariate normality, they are stable and reliable. The analysis of the standardized residuals matrix indicates no serious cases of variables with high values shared between them $(z>2)$. The only variable that contains a higher number of such residuals is 04 ("Doing my job gives me great satisfaction"), which it shares with five other variables. However, we decided to keep this variable in the model, since its error covariance with that of item 22 is allowed.

In terms of consistency (alphas), most of the factors present reasonable to excellent indices, as shown in Table 3, which also presents the means for each of these. The factor means show little variation amongst themselves, although they are somewhat lower for factors 4 (Autonomy) and 5 (Ethics). To better explore possible statistical differences between the means by participant in the descriptive factors

Table 2. Standardized Coefficients and Estimate Ranges from Bootstrap Samples

\begin{tabular}{|c|c|c|c|c|}
\hline \multirow[t]{2}{*}{ Factors } & \multirow[t]{2}{*}{ Items } & \multirow{2}{*}{$\begin{array}{c}\text { Estimate } \\
\text { by ML } \\
\text { SC }\end{array}$} & \multicolumn{2}{|c|}{$\begin{array}{c}\text { Estimation } \\
\text { Bootstrap } \\
\text { Samples }\end{array}$} \\
\hline & & & LL & UL \\
\hline \multirow[t]{8}{*}{ (F1) Learning and Development } & 14 & 0.77 & 0.69 & 0.83 \\
\hline & 15 & 0.76 & 0.68 & 0.83 \\
\hline & 17 & 0.75 & 0.66 & 0.81 \\
\hline & 19 & 0.72 & 0.63 & 0.79 \\
\hline & 09 & 0.65 & 0.55 & 0.74 \\
\hline & 22 & 0.63 & 0.53 & 0.72 \\
\hline & 13 & 0.59 & 0.48 & 0.68 \\
\hline & 04 & 0.55 & 0.43 & 0.66 \\
\hline \multirow{4}{*}{$\begin{array}{l}\text { (F2) Quality of Work } \\
\text { Relationships }\end{array}$} & 21 & 0.71 & 0.56 & 0.84 \\
\hline & 08 & 0.52 & 0.35 & 0.67 \\
\hline & 06 & 0.49 & 0.34 & 0.65 \\
\hline & 03 & 0.48 & 0.33 & 0.61 \\
\hline \multirow[t]{4}{*}{ (F3) Work Utility } & 16 & 0.83 & 0.76 & 0.91 \\
\hline & 24 & 0.77 & 0.68 & 0.84 \\
\hline & 02 & 0.68 & 0.57 & 0.76 \\
\hline & 05 & 0.68 & 0.56 & 0.76 \\
\hline \multirow[t]{3}{*}{ (F4) Autonomy } & 25 & 0.80 & 0.71 & 0.86 \\
\hline & 23 & 0.79 & 0.71 & 0.86 \\
\hline & 20 & 0.75 & 0.66 & 0.83 \\
\hline \multirow[t]{4}{*}{ (F5) Ethics } & 11 & 0.84 & 0.77 & 0.89 \\
\hline & 12 & 0.81 & 0.75 & 0.86 \\
\hline & 18 & 0.80 & 0.73 & 0.86 \\
\hline & 10 & 0.79 & 0.72 & 0.84 \\
\hline
\end{tabular}

Note: $\mathrm{ML}=$ Maximum Likelihood; $\mathrm{SC}=$ Standardized Coefficient (factorial); $\mathrm{LL}=$ lower limit; $\mathrm{UL}=$ upper limit. Confidence interval for the bootstrap simulations: $99 \%$; probability estimates: $\mathrm{p}<0.01$. 
and other variables, we conducted several tests (ANOVA and Pearson's correlation); the results are summarized in Table 4. Similarly to the confirmatory analysis, bootstrapping procedures were also carried out for the test statistics (1,000 samples, 99\% confidence interval); these intervals are also shown in Table 4.

What can be observed from Table 4 is that men have a higher average than women in the Learning and Development and Quality of Work Relationships factors. The educational

Table 3. Average. Standard Deviations. and Factor Consistency Index

\begin{tabular}{lll}
\hline \multicolumn{1}{c}{ Factor } & Average (DP) & Alpha \\
\hline (F1) Learning and Development & $3.51(0.55)$ & 0.85 \\
(F2) Quality of Work Relationships & $3.56(0.45)$ & 0.62 \\
(F3) Work Utility & $3.58(0.57)$ & 0.84 \\
(F4) Autonomy & $3.04(0.84)$ & 0.82 \\
(F5) Ethics & $3.14(0.84)$ & 0.87 \\
\hline
\end{tabular}

level influences three factors of the meaning of work: the lower the educational level, the higher the average factors in Learning and Development, Work Utility, and Ethics. The number of formal jobs is correlated with Learning and Development and withWork Utility (the higher the number of formal jobs in the last two years, the higher the averages assigned to those two factors). Unemployment time is correlated with the factors Autonomy and Ethics. Age is associated with four of the five factors of meaning at work. Finally, there were no significant relationships between the averages of the factors and the family income profiles.

\section{Discussion}

The discussion is organized around the guiding questions of this study. The first question concerned whether there were specificities in the meanings attributed to work by unemployed workers. The fact that the confirmatory analysis suggested the consistency of the meaningof work model

Table 4. Relationship between Meaning of Work Factors and Descriptive Variables

\begin{tabular}{|c|c|c|c|c|c|}
\hline \multirow{2}{*}{ Factor } & \multicolumn{5}{|c|}{ Variables } \\
\hline & Gender & Age & Level of Education & Formal Jobs & Time Unemployed \\
\hline \multirow[t]{4}{*}{$\mathrm{F} 1$} & $\begin{array}{l}t_{(356)}=2.84^{* *} \\
d=0.26\end{array}$ & $\begin{array}{l}r=0.21 * * \\
{[0.08 .0 .31]}\end{array}$ & $\begin{array}{l}F_{(5.349)}=4.59 * * * \\
\omega 2=0.05\end{array}$ & $\begin{array}{l}r=0.11 * \\
{[-0.003 \cdot 0.23]}\end{array}$ & \\
\hline & $\begin{array}{l}\mathrm{M}>\mathrm{F}(\Delta \mathrm{M}=0.16) \\
{[0.02 .0 .31]}\end{array}$ & & $\begin{array}{l}\text { ES }>\text { HS }(\Delta M=0.36) \\
{[0.06 .0 .67]}\end{array}$ & & \\
\hline & & & $\begin{array}{l}\mathrm{ES}>\operatorname{IHE}(\Delta M=0.57) \\
{[0.18 .0 .95]}\end{array}$ & & \\
\hline & & & $\begin{array}{l}\mathrm{ES}>\mathrm{CHE}(\Delta M=0.40) \\
{[0.01 .0 .79]}\end{array}$ & & \\
\hline \multirow[t]{2}{*}{$\mathrm{F} 2$} & $\begin{array}{l}t_{(356)}=2.52 * * \\
d=0.09\end{array}$ & $\begin{array}{c}r=0.14 * * \\
{[0.08 .0 .31]}\end{array}$ & & & \\
\hline & $\begin{array}{l}\mathrm{M}>\mathrm{F}(\Delta \mathrm{M}=0.12) \\
{[0.01 .0 .12]}\end{array}$ & & & & \\
\hline \multirow[t]{2}{*}{ F3 } & & $\begin{array}{c}r=0.24 * * \\
{[0.12 .0 .33]}\end{array}$ & $\begin{array}{c}F(5.349)=2.61 * \\
\omega 2=0.02\end{array}$ & $\begin{array}{c}r=0.11 * \\
{[-0.01 .0 .23]}\end{array}$ & \\
\hline & & & $\begin{array}{c}\mathrm{ES}>\mathrm{CHE}(\Delta M=0.45) \\
{[0.04 .0 .86]}\end{array}$ & & \\
\hline F4 & & $\begin{array}{c}r=0.11 * \\
{[-0.01 \cdot 0.24]}\end{array}$ & & & $\begin{array}{c}r=0.14^{* *} \\
{[0.01 .0 .25]}\end{array}$ \\
\hline \multirow[t]{2}{*}{ F5 } & & & $\begin{array}{l}F(5.345)=2.94 * * \\
\omega 2=0.04\end{array}$ & & $\begin{array}{c}r=0.12 * \\
{[-0.15 \cdot 0.23]}\end{array}$ \\
\hline & & & $\begin{array}{l}\mathrm{ES}>\mathrm{GD}(\Delta M=0.66) \\
{[0.06 .1 .25]}\end{array}$ & & \\
\hline
\end{tabular}

Note: $* \mathrm{p}<0.05 ; * * \mathrm{p}<0.01 ; \mathrm{p}<0.001$. In brackets. the range estimated by bootstrapping replications. with 1000 samples and $99 \%$ confidence level. Effect size ( $\omega 2$ and d); ES = Elementary School; HS= High School; IHE = Incomplete Higher Education; CHE = Complete Higher Education;GD = Graduate Degree; $\Delta \mathrm{M}=$ difference between averages of two groups. F1 = Learning and Development; F2 = Quality of Work Relationships; F3 = Work Utility; F4 = Autonomy; F5 = Ethics. 
proposed by Morin $(1996,2001)$ and Morin and Dassa (2006) points to a negative answer to Question 1, that is, there were no substantial changesto the structure envisaged by Morin's original model, which was designed for employed workers, despite the exclusion of some questions. In the absence of substantial changes, we can assume that for the participants of this study, the structure of the assignment of meaning to work is similar to that found by Morin for professional healthcare workers and management and by Bendassolli and Borges-Andrade (2011) for artists.

However, this conclusion should be analyzed with caution, as it may have been influenced by methodological decisions of this study and also by characteristics of the sample. Regarding the former, it must be noted that Morin and Dassa's (2006) instrument sometimes assumes that the person has a specific and current job (in the sense of employment - 21: "I can count on the support of my co-workers") but also assumes a broad concept of work (such as occupation/ activity in a more permanent or stable sense - 02: "My work is useful to society"). This may have led the respondents to think about work in general, as a human and social category, referring to their socialization, as predicted by MOW (1987). Moreover, the instruction that, when responding, participants should consider their recent work experience (for the reasons explained in the Method section) may also have contributed in such a way that the structure ofassigned meanings did not show substantive differences from the structure found by other studies using the same instrument.

With respect to the characteristics of the sample, the decisive factor was the length of time that most participants were unemployed (for $87 \%$, between one and two months). Apparently, the loss of a job and its consequent absence for a short time do not interfere with the way workers attach meaning to their work. This can be due to at leasttwo aspects of such an unemployment situation. The first is that this short period of unemployment may not yet be understood by the person as a lack of work, but only as a momentary withdrawal-similar to what happens over long vacation periods. This understanding may be motivated because unemployment has not yet shown its negative material effects, as these are minimized or are mitigated by the help of close relatives, unemployment insurance, or the worker's own savings. The second possible explanatory aspect of the unemployment situation concerns the possibility that the workers, even if unemployed from their formal jobs, are involved in informal activities for which, objectively and subjectively, they would retain the psychosocial functions linked to work; Coutinho (2009) describes something similar with respect to informal work.

These ideas on the influence of the duration of unemployment lead to the second question of this research, which concerns precisely whether the durationis related to the meaning attributed to work. There are two plausible answers to this question. First, resuming the previous conclusion regarding the overall structure of the meaning assigned to work within the model of Morin and Dassa (2006), we can conclude that up to a certain point (in this case, approximately two months), it is not possible to identify significant differences in the structure of the meaning assigned to work, despite the limitations discussed above. This finding seems to differ from the findings in the literature regarding the impact of the duration of unemployment on mental health indicators. Several studies have shown thateven a short duration (less than six months) is enoughfor experiencingthe harmful effects of job loss on mental health (e.g., Janlert et al., 2014; Jones, 1992; McKee-Ryan et al., 2005). Therefore, new studies could explore the possibility of differential effects of the mechanisms of psychological adaptation, which are better known in the case of mental healththan in the case of the meaning of work (Mohr \& Otto, 2011).

A second plausible answer to the question about the duration of unemploymentis related to the characteristics of the meaning factors. As shown in Table 4, there is a correlation, weak but significant, between the duration of unemployment and theAutonomy and Ethics factors. Although very speculatively, we can imagine that the longer one is unemployed, the more one appreciates (or idealizes) autonomy (to reduce cognitive dissonance with the unemployment situation), and the more one tends to emphasize the importance of respect and regard for human dignity. However, studies have pointed out the ambiguous and contradictory role of autonomy for the unemployed: although it may be valued atthe beginning of unemployment, over time it can turn into a cause of suffering because of the difficulty that the unemployed have in sustaining a temporal structure in their daily lives (e.g., Jahoda, 1982; Mohr \& Otto, 2011; Paul \& Moser, 2006a).

The third question concerned the relationship between the number of formal jobs held by the individual in recent years and the meaning attributed to work. Considering the characteristics of the instrument, the hypothesis was that there could be relationships between these. In fact, two correlations, weak but significant, were identified between the number of formal jobs and the factors Learning and Development and Work Utility. Notably, $85.2 \%$ of the participants held one to two formal jobs in the previous two years, compared to $8.3 \%$ with more than two (and up to six) jobs (6.5\% of the responses were omitted). Again, it is not possible to determine the precise number of jobs at which the correlation occurs, but only that the correlation seems to follow the accumulation of work experience (inferred from the number of formal jobs). Perhaps the variety of activities, contexts, and experiences helps explain the emphasis on the dimension of learning and growth associated with the meaning of work. This is convergent with the model used here (Morin, 1997, 2001, 2007).

These last findings should be put into perspective. It should be taken into consideration that the short duration of unemployment may have contributed to the participants having recast the memory of their experience in their last job when responding, and not the fact that they had held a number of formal jobs in recent years. Even with all of the limitations mentioned, this result indicates the importance of work experience in the attribution of meaning to work, which is consistent with the literature, in that one of the determinants of the meaning of work is work experience (MOW, 1987).

The last question guiding this study concerns the relation between the profiles of the participants (age, sex, education and income composition) and meanings attributed to work. This profile emerges from the data: older men with less 
education and greater work experience tended to assign higher values to the Learning and Development factor. This can be interpreted in two ways:due to their unemployment condition, they value and seek such a characteristic of work in order to facilitate their own employability; but they also value it due to their broader connections with the world of work through previous work experience, as already suggested.

It is noteworthy that there were no significant differences relating to the composition of household income variable. This may be explained by the fact that most of the participants (92\%) were not the only household members responsible for their own livelihood, since they were sharing income with spouses or family members.In any case, one question for future research concerns the impact of income on assignments of meaning to work: Could a situation of financial scarcity, combined with a high responsibility for family support, possibly change the meanings attributed to work, understood as a structural dimension of human existence (and not just as a job)? In the case of the impact of unemployment on mental health, the answer has been affirmative (Ezzy, 1993; Winefield, 2002).

Moving toward the end of this article, we present a summary of its findings and limitations as well as its contributions. For the summary, we can say that beyond the confirmation of the factor structure of Morin and Dassa's (2006) model, there is no evidence that this model must be adjusted for research on the meaning of work for the unemployed. This is conditioned by the limitations of this study, some of which have already been highlighted. In particular, since all the participants were recently unemployed, the sample composition strategy may have hindered the emergence of assignments of meaning that are specific to the unemployment condition. The instruction for participants to respond in light of their recent work experience may also have been similarly responsible for the results. As already explained, we decided to include this instruction in view of ambiguities in the issues that compose the Morin and Dassa instrument (2006). However, these constraints and limitations coexist with some contributions that this study has made.

This study contributes to a broadening of perspectives for understanding unemployment. It suggests, for future research, the heuristic possibility that the meaning of work factors can be used as moderating or antecedent variables of important facets of unemployment, such as mental health, well-being, and self-esteem (which are the most commonly investigated facets - e.g., McKee-Ryan et al., 2005). Researchers could operationalize explanatory models with these variables.

Another contribution concerns the issue of the length of unemployment. In research on the impact of this duration on mental health, there is evidence that the initial moments of unemployment can bring more harm than its prolonged duration, because of theactivity of adaptive mechanisms (Paul \& Moser, 2006a). Although the findings on this topic are not free of controversy (Mohr\& Otto, 2011), perhaps the impact of time on the meaning attributionprocess follows a different logic.

Prior work experience, by offeringto the individual a real contact with work activities, can influence the dimensions of the meaning assigned to work (as illustrated in the present study, which shows differences in factor 1, Learning and Development, and 3, Work Utility, for workers who have held more jobs and thereforehave more work experience). Moreover, it is likely that the continuity of the meanings that are culturally disseminated regarding work, and that also have a part in socialization processes, are guaranteed even in the absence of activity, at least temporarily. This may be associated with the centrality of work (McKee-Ryan et al., 2005).

In addition, the pressions and tensions associated with job loss probably act differently on mental health indicators, such as anxiety (due to financial difficulties resulting from loss of employment), than on values or preferences in relation to work (which are, in theory, more stable). In line with results reported by Mohr and Otto (2011) and Paul and Moser (2006b), it is important to develop research aimed at understanding meanings and expectations concerning work in order to foster action plans for the unemployed. What the unemployed expect from work can help in understanding and redirecting their integration strategies-obviously, considering the influence of personal variables (such as age, gender, education) and contextual variables (economic situation, supply of jobs). It would be useful to deepen our understanding of the effect of the duration of unemployment on those meanings/expectations.

Finally, the prospect of using the meaning of work can be added to many existing strategies of psychosocial intervention for the unemployed, specifically in the Brazilian reality (e.g., Abs \& Monteiro, 2010; Ribeiro, 2009). In the direction suggested by Mohr and Otto (2011), the focus for reintegration should also include, in addition to qualification or requalification (Vuori \& Vesalainen, 1999), a concern with understanding the consistency or lack thereof (Paul \& Moser, 2006b) between the employment sought and expectations, values, and work preferences - that is, work-self congruence, a central element in the model of the meaning of workpresented here (Morin, 1997, 2007). Such understanding would help in designing interventions for transitions and resignifications of the work trajectory, such as unemployment.

\section{References}

Abs, D., \& Monteiro, J. K. (2010). Práticas da psicologia clínica em face do sofrimento psíquico causado pelo desemprego contemporâneo. Psicologia em Estudo, 15(2), 419-426.

Aaronson, D., Mazumder, B., \& Schechter, S. (2010). What is behind the rise in long-term unemployment? Federal Reserve Bank of Chicago Economic Perspectives, 2, 28-51.

Antunes, R. (2009). Os sentidos do trabalho: Ensaio sobre a afirmação e negação do trabalho. São Paulo: Boitempo.

Argolo, M. A. D., \& Araújo. J. C T. (2004). O impacto do desemprego sobre o bem-estar psicológico dos trabalhadores da cidade de Natal. Revista de Administração Pública, 8, 161-182.

Barros, C.A., \& Oliveira, T. L. (2009). Saúde mental de trabalhadores desempregados. Revista Psicologia: Organizações e Trabalho, 9(1), 86-107. 
Bastos, R. L. A. (2011). Desemprego na região metropolitana de Porto Alegre: Aspectos da experiência dos anos 2000. Revista ABET, 10(2), 184-205.

Bendassolli, P. F., \& Borges-Andrade, J. E. (2011). Significado do trabalho nas indústrias criativas. RAE-Revista de Administração de Empresas, 51(2), 143-159.

Bendassolli, P. F., \& Gondim, S. M. (2014). Significados, sentidos e função psicológica do trabalho. Avances en Psicologia Latinoamericana, 32(1),131-147.

Brief, A., Konovsky, M., Goodwin, R., \& Link, K. (1995). Inferring the meaning of work from the effects of unemployment. Journal of Applied Social Psychology, 25, 693-71.

Byrne, B. M. (2010). Structural equation modeling with AMOS. New York: Routledge.

Cacciamali, M. C., \& Cury, E. L. (2013). Desenvolvimento, mercado de trabalho e distribuição de renda. Revista Paraense de Desenvolvimento, 34(124), 55-72.

Chahad, J. P. Z., \& Pozzo, R. G. (2013). Mercado de trabalho no Brasil na primeira década do século XXI. Temas de economia aplicada, 11-29.

Chen, L., Li, W., He, J., Wu, L., Yan, Z., \& Tang, W. (2012). Mental health, duration of unemployment, and coping strategy. $B M C$ public health, 12(1), 597.

Coelho-Lima, F., Costa, A. L. F., \& Bendassolli, P. (2013). A produção científica da Psicologia brasileira acerca do desemprego. Universitas Psychologica, 12(4), 1283-1299.

Coutinho, M. C. (2009). Sentidos do trabalho contemporâneo: as trajetórias identitárias como estratégia de investigação. Cadernos de Psicologia Social do Trabalho, 12(2), 189-202.

Departamento Intersindical de Estatística e Estudos Socioeconômicos. (1984). Sistema PED. São Paulo: DIEESE.

Departamento Intersindical de Estatística e Estudos Socioeconômicos. (2014). Mercado de trabalho metropolitano em 2013. São Paulo: DIEESE.

Dooley, D., \& Prause, J. (2004). The social costs of underemployment. New York: Cambridge University Press.

Estramiana, J. L. A. (1992). Desempleo y bienestar psicológico. Madrid: Siglo Veintiuno.

Ezzy, D. (1993). Unemployment and mental health: A critical review. Social Science and Medicine, 37, 41-52.

Galeazzi, I. (2011). Desemprego. In A. D. Cattanni \& L. Holzmann (Eds.), Dicionário de trabalho e tecnologia (pp. 100-105). Porto Alegre: Zouk.

Gallo, W., Bradley, E., Siegel, M., \&Kasl, S. (2000). Health effects of involuntary job loss among older workers. Journals of Gerontology, 55, 131-140.

Garcia, L. S., Rodarte, M. M. S., \& Braga, T. S. (2006). Desemprego de longa duração como corolário da Década Neoliberal. In J. M. Januzzi \& M. Soares (Eds.), As várias faces do mercado de trabalho no Brasil (pp. 54-78). Belo Horizonte: Fundação João Pinheiro.

Gómez, R. P., Morejón, A. R., \& Sabater, C. R. (2008). Expectativas y duración del desempleo. Revista de Psicología del Trabajo $y$ de las Organizaciones, 24(2), 129-151.

Hetschko, C., Knabe, A., \& Schöb, R. (2013). Changing identity: retiring from unemployment. Economic Journal 124(575), 149-166.

Hoorn, A., \& Maseland, R. (2013). Does a Protestant work ethic exist? Evidence from the well-being effect of unemployment. Journal of Economic Behavior \& Organization, 91, 1-12.
Instituto Brasileiro de Geografia e Estatística. (2013). Síntese de indicadores sociais: Uma análise das condições de vida da população brasileira 2013. Brasília: Autor.

International Labour Organization [ILO]. (2014). World of Work Report 2014: developing with jobs. Genebra: ILO.

International Labour Organization [ILO]. (1982). Resolutions concerning economically active population, employment, unemployment and underemployment.Genebra: ILO. Available in https://stats.oecd.org/glossary/detail.asp?ID=2791

Jahoda, M. (1982). Employment and unemployment: A socialpsychological analysis. Cambridge: Cambridge University Press.

Jahoda, M., Lazarsfeld, P. F., \& Zeisel, H. (1971). Marienthal: The sociography of na unemployed community. Chicago: AldineAtherton. (Original publicado em 1933)

Janlert, U., Winefield, A.H., \& Hammarström, A. (2014). Length of unemployment and health related outcomes: A life course analysis. European Journal of Public Health, 24(5), 1-6.

Jones, L. (1992). Specifying the temporal relationship between job loss and consequences: Implications for service delivery. Journal of Applied Social Science, 16, 37-62.

Kelvin, P. \& Jarret, J. (1985). Unemployment: its social and psychological effects. Cambridge: Cambridge University Press.

Kline, R. B. (2011). Principles and practice of structural equation modelling. New York: The Guilford Press.

Marôco, J. (2010). Análise de equações estruturais. PêroPinheiro: ReportNumber.

McKee-Ryan, F. M., \& Kinicki, A. J. (2002). Coping with job loss: A life-facet model. International Review of Industrial and Organizational Psychology, 17, 1-29.

McKee-Ryan, F.M., Song, Z., Wanberg, C.R., \& Kinicki, A.J. (2005). Psychological and physical well-being during unemployment. Journal of Applied Psychology, 90(1): 53-76.

Mclaughlin, E. (2013). Understanding unemployment. London: Routledge.

Mohr, G., \& Otto, K. (2011). Health effects of unemployment and job insecurity. In A. S. Antoniou, \& C. Cooper (Eds.), New meaning in organizational psychology and behavioral medicine (pp. 289-311). Surrey: Gower Publishing.

Morin, E. (1997). Le sens du travail pour des gestionnaires francophones. Revue Psychologie du Travail e des Organizations, 3(2/3), 26-45.

Morin, E. (2001). Os sentidos do trabalho. RAE: Revista de Administração de Empresas, 14(3), 8-19.

Morin, E. (2007). Sens du travail, santé mentale au travail et engagement organisationnel. Cahier de Recherche, 543, 99193.

Morin, E. M., \& Dassa, C. (2006). Characteristics of a meaningful work. Montréal: HEC.

Morin, E., Tonelli, M. J., \& Pliopas, A. N. V. (2007). O trabalho e seus sentidos. Psicologia \& Sociedade, 19(número especial), 47-56.

Meaning of Work International Research Team [MOW]. (1987). The meaning of work. London: Academic Press.

Paul, K. I., \& Moser, K. (2006a). Quantitative reviews in psychological unemployment eesearch: An overview In T. Kieselbach, A. Winefield, C. Boyd, \& S. Anderson (Eds.), Unemployment and health (pp. 51-59). Bowen Hills: Australian Academic Press. 
Paul, K. I., \& Moser, K. (2006b). Incongruence as an explanation for the negative mental health effects of unemployment: Metaanalytic evidence. Journal of Occupational and Organizational Psychology, 79, 595-621.

Pinheiro, L. R. S., \& Monteiro, J. K. (2007). Refletindo sobre desemprego e agravos à saúde mental. Caderno de Psicologia Social e do Trabalho, 10(2), 35-45.

Rantakeisu, U., Starrin, B., \& Hagquist, C. (1999). Financial hardship and shame. British Journal of Social Work, 29, 877-901.

Ribeiro, M. A. (2009). Estratégias micropolíticas para lidar com o desemprego: Contribuições da psicologia social do trabalho. Revista de Psicologia Política, 9(18), 331-346.

Santos, E. J. R., Ferreira, J. A., Albuquerque, C. P., Almeida, H. N., Mendonça, M. C., Silva, C. S., \& Almeida, J. G. (2010). Desemprego. Psychologica, 52(2), 35-44.

Schunck, R., \& Rogge, B. G. (2010). Unemployment and its association with health-relevant actions. International Journal of Public Health, 55(4), 271-278.

Silva, N., \& Tolfo, S. (2012). Trabalho significativo e felicidade humana: Explorando aproximações. Revista Psicologia: Organizações e Trabalho, 12(3), 341-354.
Steger, M. F., Dik, B. J., \& Duffy, R. D. (2012). Measuring meaningful work: The Work as Meaning Inventory (WAMI). Journal of Career Assessment, 20, 322-337.

Tolfo, S. R., Coutinho, M. C., Baasch, D., \&Cugnier, J. S. (2011). Sentidos y significados del trabajo. UniversitasPsychologica, 10(1), 175-188.

Vesalainen, J., \& Vuori, J. (1999). Job-seeking, adaptation and re-employment experiences of the unemployed. Journal of Community and Applied Social Psychology, 9, 383-394.

Vuori, J., \& Vesalainen, J. (1999). Labour market interventions as predictors of re-mployment, job-seeking activity and psychological distress among the unemployed. Journal of Occupational and Organizational Psychology, 72, 523-538.

Winefield, A. H. (2002). The psychology of unemployment. In L. Backman (Ed.), Psychology at the turn of the millennium (pp. 393-408). New Yourk: Psychology Press.

Winefield A. H., Tiggemann, M., Winefield, H. R., \& Goldney, R.D. (1993). Growing up with unemployment: A longitudinal study ofits psychological impact. London: Routledge.

Winkelmann, R. (2014). Unemployment. In A. C. Michalos (Ed.), Encyclopedia of quality of life and well-being research (pp. 6766-6767). Holanda: Springer.

Recebido em 26.07.2014

Primeira decisão editorial em 12.12.2014

Versão final em 21.12.2014

Aceito em 01.04.2015 